\title{
Complete oxidation of formaldehyde at room temperature over an Al-rich Beta zeolite supported platinum catalyst
}

\author{
Ling Zhang ${ }^{\mathrm{a}}$, Long Chen ${ }^{\mathrm{b}}$, Yaobin $\mathrm{Li}^{\mathrm{c}}$, Yuexin Peng ${ }^{\mathrm{a}}$, Fang Chen ${ }^{\mathrm{a}}$, Liang Wang ${ }^{\mathrm{a}}$, \\ Changbin Zhang ${ }^{\mathrm{c}}$, Xiangju Meng ${ }^{\mathrm{a}, *}$, Hong $\mathrm{He}^{\mathrm{c}}$, Feng-Shou Xiao ${ }^{\mathrm{a}, *}$ \\ ${ }^{a}$ Key Lab of Applied Chemistry of Zhejiang Province, Department of Chemistry, Zhejiang University, Hangzhou, 310007, PR China \\ ${ }^{\mathrm{b}}$ Faculty of Chemistry Biology and Materials Science, East China Institute of Technology, Fuzhou 344000, PR China \\ ${ }^{\mathrm{C}}$ Research Center for Eco-Environmental Sciences, Chinese Academy of Sciences, Shuangqing Road 18, Beijing, 100085, PR China
}

\section{A R T I C L E I N F O}

\section{Article history:}

Received 17 January 2017

Received in revised form 4 July 2017

Accepted 7 July 2017

Available online 8 July 2017

\section{Keywords:}

Formaldehyde

Complete oxidation

Room temperature

Al-rich Beta zeolite

\begin{abstract}
A B S T R A C T
For human health and environmental protection, removal of formaldehyde (HCHO) has become a hot topic, and completely catalytic oxidation at room temperature has been identified as one of the efficient routes for solving this problem. Recently, it has been reported that zeolite-supported Pt catalysts are active for $\mathrm{HCHO}$ oxidation at low temperatures, but they are still unable to completely oxidize $\mathrm{HCHO}$ at room temperature. To enhance the activity, it has been suggested to increase the Pt dispersion and acidic density in the zeolite-supported Pt catalysts. We therefore chose Al-rich Beta as a zeolite support because abundant aluminum species in the zeolite framework are advantageous for increasing acidic density through ion-exchange of protons and for improving Pt metal dispersion through the metalzeolite interaction by increasing the negative charge of the zeolite framework with positively charged metal ions. As we expected, the Al-rich Beta zeolite supported platinum catalyst is very active, giving complete oxidation of $\mathrm{HCHO}$ at room temperature. To the best of our knowledge, this is the first time the complete oxidation of $\mathrm{HCHO}$ at room temperature over a zeolite-supported noble metal catalyst has been realized. In addition to its extraordinary activity, this catalyst is also very stable and selective. The strategy of designing zeolite-supported noble metal catalysts might offer an alternative way to develop highly efficient heterogeneous catalysts for the removal of air pollutants.
\end{abstract}

(C) 2017 Published by Elsevier B.V.

\section{Introduction}

Formaldehyde ( $\mathrm{HCHO})$ is one of the major components of indoor air pollutants due to its broad applications in decorating and furnishing materials, which results in great threats to human health [1-14]. Therefore, the highly efficient removal of HCHO has been intensively studied in the past decades, and a series of techniques such as adsorption [15-18], photocatalysis [19-25], plasma technology [26-29] and catalytic oxidation [30-37] have been well developed. Among them, complete catalytic oxidation has been identified as one of the most efficient routes for $\mathrm{HCHO}$ abatement due to its non-toxic by-products and high activity at low temperatures [4,30,38-42]. Supported transition metal oxides and/or noble metals are the most useful catalysts for the catalytic oxidation of HCHO [30,38-55]. Compared with supported transition metal oxides, supported noble metals exhibit high activity

\footnotetext{
* Corresponding authors.

E-mail addresses: mengxj@zju.edu.cn (X. Meng), fsxiao@zju.edu.cn (F.-S. Xiao).
}

[30,38-43,45,48-51,53,54]. Normally, titania [53,56-59], alumina [60-62] and silica [63-65] have been applied as supports for preparation of these noble metal catalysts, but recently, zeolite supports have received much attention for this oxidation, owing to their large surface areas, intricate channels, high adsorption capacity, adjustable acidic property, and high thermal and hydrothermal stabilities [66-70]. Notably, zeolite supported noble metal catalysts still show lower activities in the complete oxidation of $\mathrm{HCHO}$ than titania supported noble metal catalysts modified with alkaline cations $[43,45,48,49,51,53,54,65]$. Therefore, it is strongly desirable to develop highly efficient zeolite supported noble metal catalysts for the complete oxidation of $\mathrm{HCHO}$ at low temperatures, particularly at room temperature.

It has been reported that the presence of acidic sites is favorable for the oxidation of oxygenates at low temperatures [71] and enhancement of the metal-support interaction is helpful for high dispersion of the metal on the support $[72,73]$. Therefore, design strategies for improving activity in the complete oxidation of $\mathrm{HCHO}$ involve in increasing metal dispersion and acidic density in the zeolite supported noble metal catalysts. 
To realize these strategies, we chose Al-rich Beta as the zeolite support [74-77] because abundant aluminum species in the zeolite framework are advantageous for increasing acidic density by ion-exchange of protons and for improving metal-zeolite interaction by increasing the negative charge of the zeolite framework with positively charged metals. As we expected, the Al-rich Beta zeolite supported platinum catalyst (Pt/H-Beta-SDS-4) shows complete oxidation of $\mathrm{HCHO}$ at room temperature. The catalysts were characterized by physical and chemical techniques, and their catalytic performance for $\mathrm{HCHO}$ oxidation was evaluated.

\section{Experimental}

\subsection{Materials}

$\mathrm{NaAlO}_{2}$, formaldehyde solution, and $\mathrm{NaOH}$ were purchased from Sinopharm Chemical Reagent. Fumed silica $\left(\mathrm{SiO}_{2}\right)$ was obtained from Shenyang Chemical Co. Beta seeds ( $\mathrm{Si} / \mathrm{Al}$ at 12.50) were supplied from Nankai University Catalyst Co. Tetraethylammonium

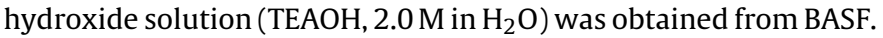
$\mathrm{H}_{2} \mathrm{PtCl}_{6} \cdot 6 \mathrm{H}_{2} \mathrm{O}$, nitric acid, formic acid, and $\mathrm{KNO}_{3}$ were purchased from Aladdin. All these materials were of analytical grade and used without further purification.

\subsection{Preparation of catalysts}

Synthesis of Beta-SDS and Beta-TEA: Seed-directed synthesis of Beta zeolite (Beta-SDS) was carried out in the presence of calcined Beta zeolite seeds. As a typical run, $3.2 \mathrm{~g} \mathrm{NaAlO}$ and $5.6 \mathrm{~g} \mathrm{NaOH}$ were dissolved in $68 \mathrm{~mL}$ of $\mathrm{H}_{2} \mathrm{O}$, followed by addition of $20 \mathrm{~g}$ of fumed silica [75]. After stirring for $12 \mathrm{~h}, 1 \mathrm{~g}$ of Beta zeolite seeds were introduced into the gel, followed by stirring for $5 \mathrm{~min}$. Then, the resulting gel was transferred into an autoclave for crystallization at $120^{\circ} \mathrm{C}$ for $90 \mathrm{~h}$. After filtering, washing with water at room temperature, and drying at $100^{\circ} \mathrm{C}$ in air for $12 \mathrm{~h}$, the solid product of Beta-SDS was finally obtained. The ICP-OES analysis of this BetaSDS showed that the Si/Al ratio was 4.28. Therefore, this sample was designated as Beta-SDS-4.

Beta zeolite (Beta-TEA) was synthesized in the presence of TEA ${ }^{+}$ cations. As a typical run, $1.5 \mathrm{~g}$ of $\mathrm{NaAlO}_{2}$ and $0.8 \mathrm{~g}$ of $\mathrm{NaOH}$ were dissolved in $63 \mathrm{~mL} \mathrm{H}_{2} \mathrm{O}$, followed by addition of $97 \mathrm{~mL}$ of TEAOH [78]. After stirring for $10 \mathrm{~min}, 24 \mathrm{~g}$ of fumed silica was introduced into the gel, followed by stirring for $12 \mathrm{~h}$. Then, the resulting gel was transferred into an autoclave for crystallization at $140^{\circ} \mathrm{C}$ for $96 \mathrm{~h}$. After filtrating, washing with water at room temperature, drying at $100^{\circ} \mathrm{C}$ in air for $12 \mathrm{~h}$, and calcining at $550^{\circ} \mathrm{C}$ for $5 \mathrm{~h}$ for removing the organic templates, the solid product of Beta-TEA was finally obtained. The ICP-OES analysis of this Beta-TEA showed that the $\mathrm{Si} / \mathrm{Al}$ ratio was 11.67. Therefore, this sample was designated as BetaTEA-12.

Beta-SDS samples with Si/Al ratios at 7.88 and 10.12 were prepared with acidic treatment of Beta-SDS- 4 in $0.3 \mathrm{M} \mathrm{HNO}_{3}$ and $0.6 \mathrm{M}$ $\mathrm{HNO}_{3}$ for $3 \mathrm{~h}$, which were designated as Beta-SDS-8 and Beta-SDS10.

The $\mathrm{H}^{+}$-form of Beta-SDS (H-Beta-SDS) and Beta-TEA-12 (HBeta-TEA-12) samples was prepared from $\mathrm{NH}_{4}{ }^{+}$-exchange of Na-Beta-SDS and Na-Beta-TEA-12, followed by calcination at $500{ }^{\circ} \mathrm{C}$ for $4 \mathrm{~h}$. To decrease $\mathrm{Na}^{+}$concentration in the sample, the ion-exchange procedures were repeated for twice. Similarly, KBeta-SDS-4 sample was ion-exchanged with $\mathrm{KNO}_{3}$ solution $(1 \mathrm{M})$ at $80^{\circ} \mathrm{C}$ for $3 \mathrm{~h}$ for twice.

Preparation of zeolite Beta supported Pt catalysts: The zeolite Beta-supported Pt catalysts were prepared by an impregnation using an appropriate amount of aqueous solution of $\mathrm{H}_{2} \mathrm{PtCl}_{6} \cdot 6 \mathrm{H}_{2} \mathrm{O}$. After impregnation, the excessive water was removed in a rotary evaporator at $80^{\circ} \mathrm{C}$. The samples were dried at $120^{\circ} \mathrm{C}$ for $12 \mathrm{~h}$ and then calcined at $400^{\circ} \mathrm{C}$ for $4 \mathrm{~h}$. The loading of Pt was $1.0 \mathrm{wt} \%$.

\subsection{Catalyst characterization}

The crystalline structure of the samples was determined by a powder X-ray diffractometer (Rigaku Ultimate VI X-ray diffractometer) using $\mathrm{Cu} \mathrm{K \alpha}(\lambda=1.5406 \AA)$ radiation at $40 \mathrm{kV}$ and $40 \mathrm{~mA}$ with the step size of $0.065^{\circ}(2 \theta)$.

A physisorption analyzer (Micromeritics ASAP $2020 \mathrm{M}$ and Tristar system) was used to measure the surface area and pore structure (volume and size) of the samples by $\mathrm{N}_{2}$ adsorption-desorption at $77 \mathrm{~K}$. All samples were degassed at $90^{\circ} \mathrm{C}$ for $12 \mathrm{~h}$ to remove the physisorbed moisture before the $\mathrm{N}_{2}$ adsorption. The surface area was calculated from using the Brunauer-Emmett-Teller (BET) method.

The $\mathrm{Si} / \mathrm{Al}$ ratios of Beta zeolites and the Pt loading in the samples was conducted using an inductively coupled plasma with a PerkinElmer plasma 8000 optical emission spectrometer (ICP-OES). All samples were dissolved using strong acid solution before being tested.

For the morphology study, the Beta materials were investigated using a Hitachi SU 1510 apparatus scanning electron microscopy (SEM), and the accelerating voltage was $20 \mathrm{kv}$. High-resolution TEM (HR-TEM) experiments were performed at $200 \mathrm{kV}$ on a JEOL $2100 \mathrm{~F}$ electron microscope.

The platinum dispersion of the samples was assessed by $\mathrm{H}_{2}$ chemisorption at $25^{\circ} \mathrm{C}$, performed using a Finetec Finesorb-3010 instrument equipped with a TCD. Typically, $0.05 \mathrm{~g}$ of the sample was pretreated in a pure $\operatorname{Ar}$ flow $(20 \mathrm{~mL} / \mathrm{min})$ at $200^{\circ} \mathrm{C}$ for $0.5 \mathrm{~h}$ and then cooled down to $25^{\circ} \mathrm{C}$. Pulse chemisorption measurements were performed at this temperature with $10 \% \mathrm{H}_{2} / \mathrm{Ar}(20 \mathrm{~mL} / \mathrm{min})$.

The adsorption and desorption of formaldehyde was performed on a Finetec Finesorb-3010 instrument equipped with a thermal conductivity detector and programmed heating. In a typical run, $50 \mathrm{mg}$ of sample were pre-treated in a pure He flow $(15 \mathrm{~mL} / \mathrm{min})$ at $200{ }^{\circ} \mathrm{C}$ for $0.5 \mathrm{~h}$ and then cooled down to $25^{\circ} \mathrm{C}$ prior to the adsorption of formaldehyde for $1 \mathrm{~h}$. After saturation with formaldehyde, the sample was flushed with pure $\mathrm{He}(15 \mathrm{~mL} / \mathrm{min})$ for $1 \mathrm{~h}$ at $25^{\circ} \mathrm{C}$. The profiles of desorbed species were recorded online at a heating rate of $10^{\circ} \mathrm{C} / \mathrm{min}$.

The acidity of the samples was measured by the temperatureprogrammed-desorption of ammonia ( $\mathrm{NH}_{3}-\mathrm{TPD}$ ) on a Micromeritics AutoChem II 2920. The sample (0.2 g, 40-60 mesh) was pretreated at $500^{\circ} \mathrm{C}$ in a $\mathrm{N}_{2}$ flow for $60 \mathrm{~min}$, followed by the adsorption of $\mathrm{NH}_{3}$ at $100^{\circ} \mathrm{C}$ for $30 \mathrm{~min}$. After saturation, the sample was purged by $\mathrm{N}_{2}$ flow for $30 \mathrm{~min}$ at $100^{\circ} \mathrm{C}$ to remove the physically adsorbed ammonia on the sample. Then, desorption of $\mathrm{NH}_{3}$ was carried out from 100 to $600^{\circ} \mathrm{C}$ with a heating rate of $10^{\circ} \mathrm{C} / \mathrm{min}$.

$\mathrm{X}$-ray photoelectron spectra (XPS) of the samples were recorded using a Thermo ESCALAB 250 with $\mathrm{Al} K \alpha \mathrm{X}$-ray radiation for the Xray source. The binding energies (BEs) were calibrated against $\mathrm{C} 1 \mathrm{~s}$ $(285.0 \mathrm{eV})$ and $\mathrm{Al} 2 \mathrm{p}(73.9 \mathrm{eV})$ peaks.

\subsection{Catalytic tests}

Complete oxidation of formaldehyde was performed in a continuous flow fixed-bed microreactor at the atmospheric pressure, consisting of a quartz tube ( $4 \mathrm{~mm}$ internal diameter) that was filled with the catalyst. A typical experiment was performed using a catalytic bed of $100 \mathrm{mg}$ of catalyst (40-60 mesh) with total flow rate of feed stream at $100 \mathrm{~mL} / \mathrm{min}$ (The feed gas composition was $400 \mathrm{ppm}$ $\mathrm{HCHO}, 20 \% \mathrm{O}_{2}$, He as balance), $50 \%$ relative humidity (RH), and a space velocity (SV) of $60,000 \mathrm{~mL} /(\mathrm{gh})$. The RH of the feed gas was determined by a high accuracy thermo-hygrometer with a probe (WSB-2-H2, Zhengzhou Boyang). Gaseous HCHO was generated by 
flowing He over paraformaldehyde, which was placed in a thermostatic water bath. As the same with previous activity evaluating instruments and methods [52,79], the inlet and outlet gases were monitored by FTIR (Nicolet iS50 equipped with $2 \mathrm{~m}$ gas cell and a DTGS detector, resolution: $0.5 \mathrm{~cm}^{-1}$, OPD velocity: $0.4747 \mathrm{~cm} \mathrm{~s}^{-1}$ ). The collected region was $600-4000 \mathrm{~cm}^{-1}$ and the number of scans per spectrum was 16 times. $\mathrm{HCHO}$ and $\mathrm{CO}_{2}$ were measured by the peaks located at 2897 ( $\mathrm{C}-\mathrm{H}$ vibration) and $2350 \mathrm{~cm}^{-1}(\mathrm{O}-\mathrm{C}-\mathrm{O}$ vibration), respectively. The $\mathrm{CO}_{2}$ concentrations were quantified and calculated based on the peak area of $\mathrm{CO}_{2}$ at $2350 \mathrm{~cm}^{-1}$. Since no other carbon containing compounds except for $\mathrm{CO}_{2}$ were detected in the effluents for all tested samples, the conversion was calculated from a carbon balance that $1 \mathrm{~mol}$ of $\mathrm{HCHO}$ forms $1 \mathrm{~mol}$ of $\mathrm{CO}_{2}$.

Kinetic rates in oxidation of $\mathrm{HCHO}$ to $\mathrm{CO}_{2}$ with $\mathrm{H}_{2} \mathrm{O}$ and oxidation of $\mathrm{HCOOH}$ to $\mathrm{CO}_{2}$ with $\mathrm{H}_{2} \mathrm{O}$ were measured in a gaseous flowing fixed reactor, while kinetic rates in oxidation of $\mathrm{HCHO}$ to $\mathrm{HCOOH}$ were measured in a liquid reactor.

The kinetic measurements for oxidation of $\mathrm{HCHO}$ to $\mathrm{CO}_{2}$ with $\mathrm{H}_{2} \mathrm{O}$ were implemented from the $\mathrm{HCHO}$ conversion below $15 \%$, $\mathrm{HCHO}$ concentration of $3000 \mathrm{ppm}, \mathrm{GHSV}$ at $240,000 \mathrm{~mL} /\left(\mathrm{g}_{\text {cat }} \cdot \mathrm{h}\right)$, temperature at $25^{\circ} \mathrm{C}$, relative humidity $(\mathrm{RH})$ at $50 \%, \mathrm{O}_{2}$ of $20 \%(\mathrm{He}$ as a balance gas), and flow rate of $100 \mathrm{~mL} / \mathrm{min}$. The kinetic measurements for oxidation of $\mathrm{HCOOH}$ to $\mathrm{CO}_{2}$ with $\mathrm{H}_{2} \mathrm{O}$ were implemented from the $\mathrm{HCOOH}$ conversion below $15 \%, \mathrm{HCOOH}$ concentration of $3000 \mathrm{ppm}, \mathrm{GHSV}$ at $240,000 \mathrm{~mL} /\left(\mathrm{g}_{\text {cat }} \cdot \mathrm{h}\right)$, temperature at $25^{\circ} \mathrm{C}$, relative humidity $(\mathrm{RH})$ at $50 \%, \mathrm{O}_{2}$ of $20 \%$ (He as a balance gas), and flow rate of $100 \mathrm{~mL} / \mathrm{min}$. In these measurements, $\mathrm{HCHO}, \mathrm{HCOOH}$ and $\mathrm{CO}_{2}$ were calculated from the peak intensities located at $2897 \mathrm{~cm}^{-1}$ (C-H vibration) for $\mathrm{HCHO}, 1340 \mathrm{~cm}^{-1}$ (C-H vibration) for $\mathrm{HCOOH}$, and $2350 \mathrm{~cm}^{-1}$ (O-C-O vibration) for $\mathrm{CO}_{2}$, respectively. Since no other carbon containing compounds except for $\mathrm{CO}_{2}$ were detected in the effluents for all tested samples, the conversion was calculated from a carbon balance that $1 \mathrm{~mol}$ of $\mathrm{HCHO}$ forms $1 \mathrm{~mol}$ of $\mathrm{CO}_{2}$ and $1 \mathrm{~mol}$ of $\mathrm{HCOOH}$ forms $1 \mathrm{~mol}$ of $\mathrm{CO}_{2}$.

Kinetic measurements for oxidation of $\mathrm{HCHO}$ to $\mathrm{HCOOH}$ were implemented from the formaldehyde conversion below $5 \%, \mathrm{HCHO}$ concentration of $0.06715 \mathrm{~mol} / \mathrm{L}$, solution volume of $50 \mathrm{~mL}$, catalyst of $0.05 \mathrm{~g}$, reaction temperature at $25^{\circ} \mathrm{C}$, and reaction for $5 \mathrm{~h}$. The reactants and products were analyzed by a Shimadzu GC-2014 chromatograph equipped with FID detector and a Agilent HP6890 Gas chromatography-mass spectrometry.

\section{Results and discussion}

\subsection{Catalytic performances in $\mathrm{HCHO}$ oxidation}

Fig. 1 shows dependences of $\mathrm{HCHO}$ conversion on reaction temperature in $\mathrm{HCHO}$ oxidation over the various catalysts under $\mathrm{HCHO}$ concentration of $400 \mathrm{ppm}$. Before the tests, all catalysts were pretreated in flowing $\mathrm{H}_{2}$ at $300^{\circ} \mathrm{C}$ for $2 \mathrm{~h}$. For the Pt/H-Beta-TEA-12 catalyst, the temperature for complete oxidation of $\mathrm{HCHO}$ is $\mathrm{ca}$. $46^{\circ} \mathrm{C}$, which is very similar to the temperatures of zeolite supported Pt catalysts reported previously [69,80]. In contrast, all $\mathrm{Pt} / \mathrm{H}$-Beta-SDS catalysts show much lower temperatures for complete oxidation of $\mathrm{HCHO}$ under the same condition (Table S1). Neither $\mathrm{CO}$ nor small organic molecules could be detected in the tail gas, and $\mathrm{CO}_{2}$ together with $\mathrm{H}_{2} \mathrm{O}$ are the only products. Notably, the catalytic activities catalysts quantitatively improve with the decrease of the zeolite Si/Al ratios, as shown in Figs. S1-S5, which might be attributed to increasing acidic density and Pt dispersion in the catalysts. Particularly, Pt/H-Beta-SDS-4 sample exhibits room temperature $\left(25^{\circ} \mathrm{C}\right)$ for the complete oxidation of $\mathrm{HCHO}$.

Fig. 2 shows the dependences of the conversion on the reaction time of HCHO oxidation over the Pt/H-Beta-SDS-4 under an initial $\mathrm{HCHO}$ concentration ranging from 80 to $800 \mathrm{ppm}$ at $25^{\circ} \mathrm{C}$.

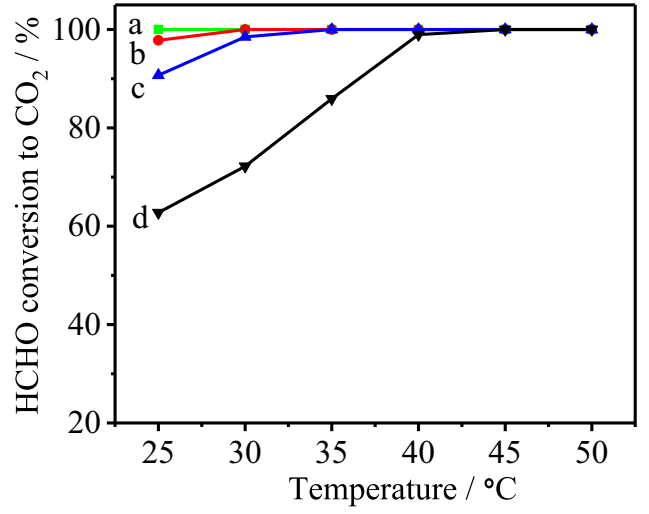

Fig. 1. Dependences of $\mathrm{HCHO}$ conversion on reaction temperature in $\mathrm{HCHO}$ oxidation over the (a) Pt/H-Beta-SDS-4, (b) Pt/H-Beta-SDS-8, (c) Pt/H-Beta-SDS-10, and (d) $\mathrm{Pt} / \mathrm{H}$-Beta-TEA-12 catalysts under $\mathrm{HCHO}$ concentration of $400 \mathrm{ppm}, \mathrm{O}_{2} 20 \%$, rate of $100 \mathrm{~mL} / \mathrm{min}$, space velocity of $60000 \mathrm{~mL} / \mathrm{g} \cdot \mathrm{h}$, relative humidity of $50 \%$, and He as the balance gas.

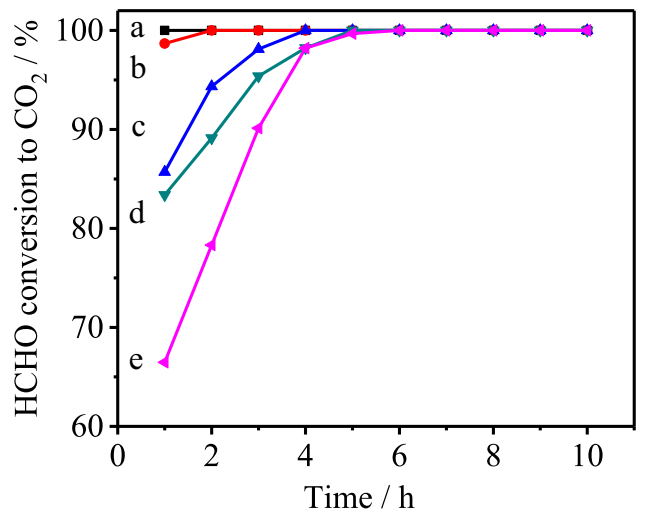

Fig. 2. Dependences of HCHO conversion on reaction time with initial HCHO concentration of (a) 80 , (b) 200 , (c) 400, (d) 600, and (e) 800 ppm in the HCHO oxidation over the Pt/H-Beta-SDS-4 catalyst under $\mathrm{O}_{2} 20 \mathrm{vol} \%$ (He as a balance gas), total flow rate $100 \mathrm{~cm}^{3} / \mathrm{min}$, relative humidity (RH) at $50 \%, \mathrm{SV}=60,000 \mathrm{~mL} /(\mathrm{g} \cdot \mathrm{h})$, and temperature at $25^{\circ} \mathrm{C}$.

Evidently, $\mathrm{HCHO}$ at various concentrations could be completely oxidized into $\mathrm{CO}_{2}$, but a higher initial concentration requires a longer time to achieve the full oxidation of $\mathrm{HCHO}(100 \%)$. When the space velocity of the reaction is increased from $60000 \mathrm{~mL} / \mathrm{g} \mathrm{h}$ to $240000 \mathrm{~mL} / \mathrm{g}$ h, the $\mathrm{Pt} / \mathrm{H}$-Beta-SDS-4 still gives a complete oxidation of $\mathrm{HCHO}$ (Fig. S6). If the relative humidity is changed to higher than $90 \%$, the $\mathrm{Pt} / \mathrm{H}$-Beta-SDS-4 needs much less time to reach the complete oxidation of $\mathrm{HCHO}$ at room temperature (Fig. S7). In contrast, if $\mathrm{H}_{2} \mathrm{O}$ is absent in the system, the sample shows relatively lower activity. Fig. 3 shows dependences of catalytic activity and selectivity on reaction time under $\mathrm{HCHO}$ concentrations of $400 \mathrm{ppm}$ and $5000 \mathrm{ppm}$, respectively. When the $\mathrm{HCHO}$ concentration is 400 ppm, the Pt/H-Beta-SDS-4 Exhibits 100\% HCHO conversion and $\mathrm{CO}_{2}$ selectivity. When the $\mathrm{HCHO}$ concentration reaches $5000 \mathrm{ppm}$, the conversion reduces to $35 \%$, but the selectivity still remains $100 \%$ over the $\mathrm{Pt} / \mathrm{H}$-Beta-SDS- 4 . These results demonstrate that the Pt/H-Beta-SDS-4 sample is highly active, very selective, and extraordinarily durable for the complete oxidation of $\mathrm{HCHO}$ at room temperature.

Fig. S8 shows the dependences of $\mathrm{HCHO}$ conversion on reaction temperature in $\mathrm{HCHO}$ oxidation over the Pt/H-Beta-SDS-4 samples pretreated at various temperatures under flowing hydrogen under $\mathrm{HCHO}$ concentration of $400 \mathrm{ppm}$, and their complete oxidation temperature for $\mathrm{HCHO}$ are summarized in Table S2. Apparently, $\mathrm{Pt} / \mathrm{H}$-Beta-SDS sample pretreated in flowing $\mathrm{H}_{2}$ at $300^{\circ} \mathrm{C}$ is suit- 

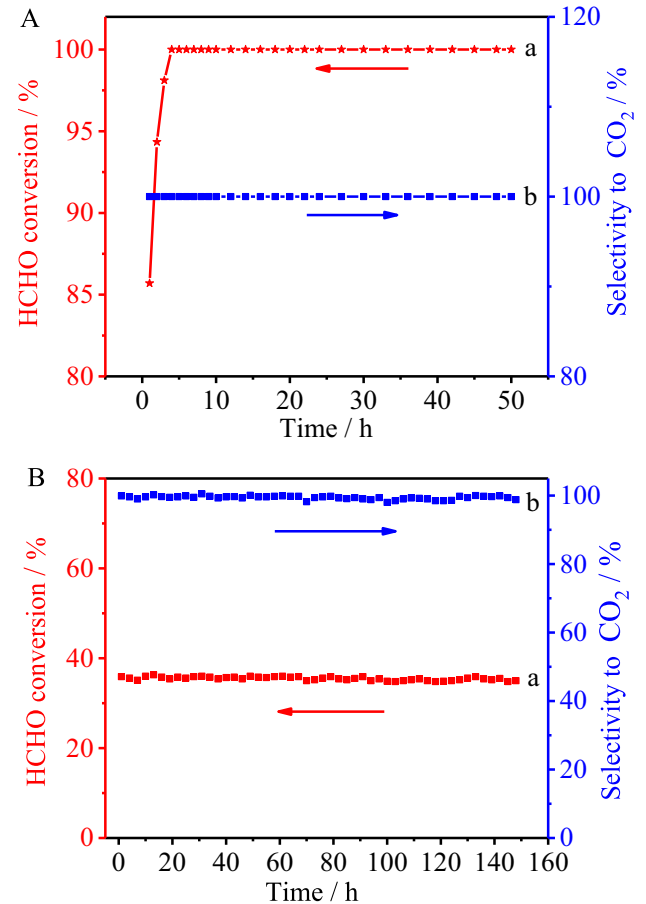

Fig. 3. Dependence of activities on reaction time in $\mathrm{HCHO}$ conversion (a) and selectivity to $\mathrm{CO}_{2}$ (b) over Pt/H-Beta-SDS-4 catalyst under the conditions of $\mathrm{HCHO}$ concentration at (A) $400 \mathrm{ppm}$ and (B) $5000 \mathrm{ppm}, \mathrm{O}_{2}$ concentration of $20 \mathrm{vol} \%$, He as balance, total flow rate of $100 \mathrm{~cm}^{3} / \mathrm{min}$, relative humidity (RH) at $50 \%$, space velocity of $60,000 \mathrm{~mL} /(\mathrm{g} \mathrm{h})$, and reaction temperature at $25^{\circ} \mathrm{C}$.

able for complete oxidation of $\mathrm{HCHO}$ at room temperature, which might be related to the valence state of Pt species in the catalysts.

Fig. S9 shows the Pt4d XPS spectra of as-synthesized Pt/H-BetaSDS- 4 and this sample pretreated at 200,300 , and $400{ }^{\circ} \mathrm{C}$. After deconvolution $[81,82]$, the proportions of $\mathrm{Pt}^{0}$, denoted as $P\left(\mathrm{Pt}^{0}\right)$, in these samples could be estimated, as presented in Table S3. Interestingly, the $\mathrm{Pt}^{0}$ concentration pretreated at $300^{\circ} \mathrm{C}$ was $57 \%$; there is almost no change in the $\mathrm{Pt}^{0}$ concentration for pretreated temperature from $300^{\circ} \mathrm{C}$ to $400^{\circ} \mathrm{C}$. Therefore, the pretreatment in flowing $\mathrm{H}_{2}$ at $300^{\circ} \mathrm{C}$ is suitable for complete oxidation of $\mathrm{HCHO}$ at room temperature, where relatively high $\mathrm{Pt}^{0}$ concentration in the samples has been achieved. These results suggest that the control of Pt valence state in the samples is a critical factor for $\mathrm{HCHO}$ oxidation.

\subsection{Catalyst characterizations}

Fig. 4 shows XRD pattern and $\mathrm{N}_{2}$ sorption isotherms of the Pt/HBeta catalysts with various $\mathrm{Si} / \mathrm{Al}$ ratios. As shown in Fig. 4A, XRD patterns of the H-Beta-SDS-4, H-Beta-SDS-8, H-Beta-SDS-10, and H-Beta-TEA-12 supported noble metal Pt samples exhibited wellresolved characteristic peaks associated with Beta zeolite structure but the introduction of Pt did not induce the appearances of the peaks of polycrystalline noble metals, which indicates that the Pt are in very high dispersion degree on the samples. Fig. 4B shows $\mathrm{N}_{2}$ sorption isotherms of all samples, giving very similar curves below the relative pressure $\left(\mathrm{P} / \mathrm{P}_{0}\right)$ of 0.95 . As a result, both samples exhibit very similar BET surface areas and micropore volumes, as presented in Table 1 . In addition, the SEM images of all samples show that they have almost the same crystal sizes, as given in Fig. 5. Considering that the all samples have almost the same textural parameters (Fig. 4 and Table 1) and zeolite crystal sizes (Fig. 5), it is proposed that the difference in their catalytic activities might be resulted from their distinguishable Pt nanoparticles and acidic density.
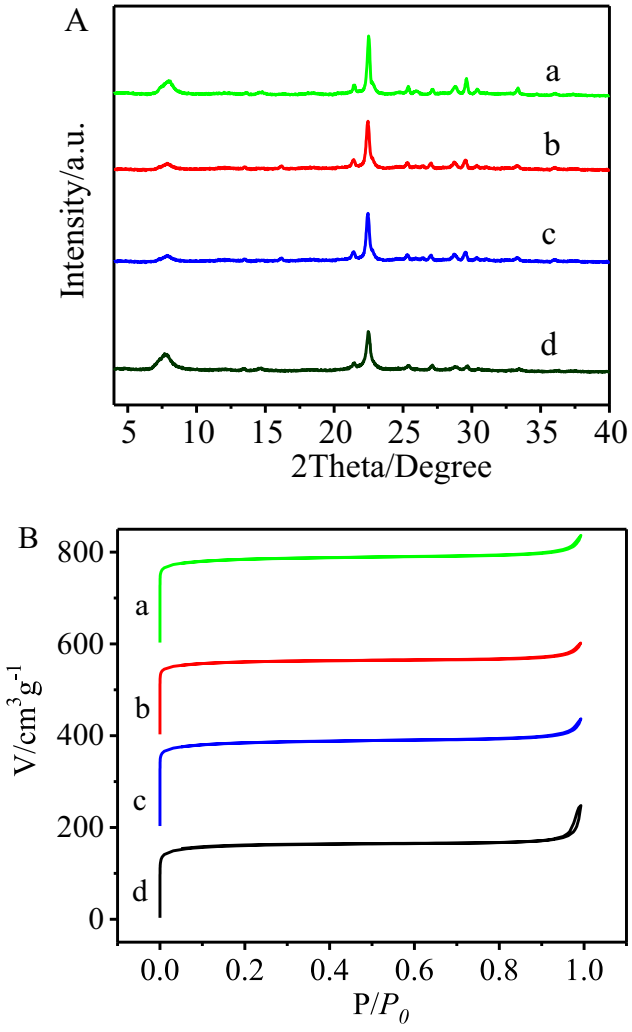

Fig. 4. (A) XRD patterns, and (B) $\mathrm{N}_{2}$ sorption isotherms of (a) Pt/H-Beta-SDS-4 (b) Pt/H-Beta-SDS-8, (c) Pt/H-Beta-SDS-10, and (d) Pt/H-Beta-TEA-12 catalysts. The isotherms (a)-(c) in Fig. 4B have been off-set by 600,400 , and $200 \mathrm{~cm}^{3} / \mathrm{g}$ at the beginning for clarity, respectively.

Fig. 6 shows HRTEM images and Pt nanoparticle size distribution of the $\mathrm{Pt} / \mathrm{H}$-Beta catalysts with various $\mathrm{Si} / \mathrm{Al}$ ratios. Interestingly, the Pt size distribution of Pt/H-Beta-SDS-4 is clearly smaller than those of other samples, as confirmed by the estimation of platinum dispersion from $\mathrm{H}_{2}$ chemisorption (Table 1). Interestingly, the platinum dispersion significantly enhances with the decrease of the zeolite Si/Al ratio, as shown in Fig. S10. This phenomenon might be related to the $\mathrm{H}$-Beta-SDS- 4 having more negative charge in the zeolite framework than other samples, which should be favorable for the interaction of positively charged Pt with the negatively charged zeolite framework, leading to higher Pt dispersion in the sample, in good agreement with results reported previously $[72,73]$.

The acidic density of the $\mathrm{Pt} / \mathrm{H}$-Beta catalysts with various $\mathrm{Si} / \mathrm{Al}$ ratios has been investigated by $\mathrm{NH}_{3}-\mathrm{TPD}$ technique $[74,76]$, as shown in Fig. S11. The results indicate that the acidic density effectively increases with $\mathrm{Al}$ amount in the catalysts. Because the $\mathrm{Pt} / \mathrm{H}-$ Beta-SDS- 4 has more 4-coordinative $\mathrm{Al}^{3+}$ in the zeolite framework than the other catalysts, the Pt/H-Beta-SDS-4 exhibits much higher acidic density than the other samples. High acidic density in the $\mathrm{Pt} / \mathrm{H}$-Beta-SDS-4 is perhaps beneficial to the activation of $\mathrm{HCHO}$ reactant, possibly due to the relatively strong interaction of $\mathrm{HCHO}$ molecules with acidic species of the zeolite. This explanation is evidently supported by the adsorption of $\mathrm{HCHO}$ (HCHO-TPD), followed by the programmed desorption of the samples, where the $\mathrm{Pt} / \mathrm{H}$ Beta-SDS-4 shows much stronger signal intensity than the other samples (Fig. 7).

\subsection{Kinetic studies}

To understand the higher activity in the HCHO oxidation over the $\mathrm{Pt} / \mathrm{H}$-Beta-SDS- 4 than that over the other sample, the reactant 
Table 1

Textural parameters of the Pt/H-Beta-SDS-4, Pt/H-Beta-SDS-8, Pt/H-Beta-SDS-10, and Pt/H-Beta-TEA-12 samples.

\begin{tabular}{|c|c|c|c|c|c|}
\hline Catalyst & $\mathrm{Si} / \mathrm{Al}^{\mathrm{a}}$ & $\mathrm{Pt}^{\mathrm{a}}(\mathrm{wt} \%)$ & $\mathrm{BET}^{\mathrm{b}} \mathrm{m}^{2} / \mathrm{g}$ & $\mathrm{V}^{\mathrm{b}}$ micro $\mathrm{cm}^{3} / \mathrm{g}$ & Platinum dispersion ${ }^{\mathrm{C}}(\%)$ \\
\hline Pt/H-Beta-SDS-4 & 4.28 & 0.976 & 541 & 0.25 & 45 \\
\hline Pt/H-Beta-SDS-8 & 7.88 & 0.985 & 532 & 0.23 & 41 \\
\hline Pt/H-Beta-SDS-10 & 10.12 & 0.994 & 539 & 0.24 & 36 \\
\hline Pt/H-Beta-TEA-12 & 11.67 & 0.989 & 540 & 0.24 & 33 \\
\hline
\end{tabular}

a Determined from the ICP-OES analysis.

b Determined from the $\mathrm{N}_{2}$ sorption isotherms

c Determined from $\mathrm{H}_{2}$ chemisorption.
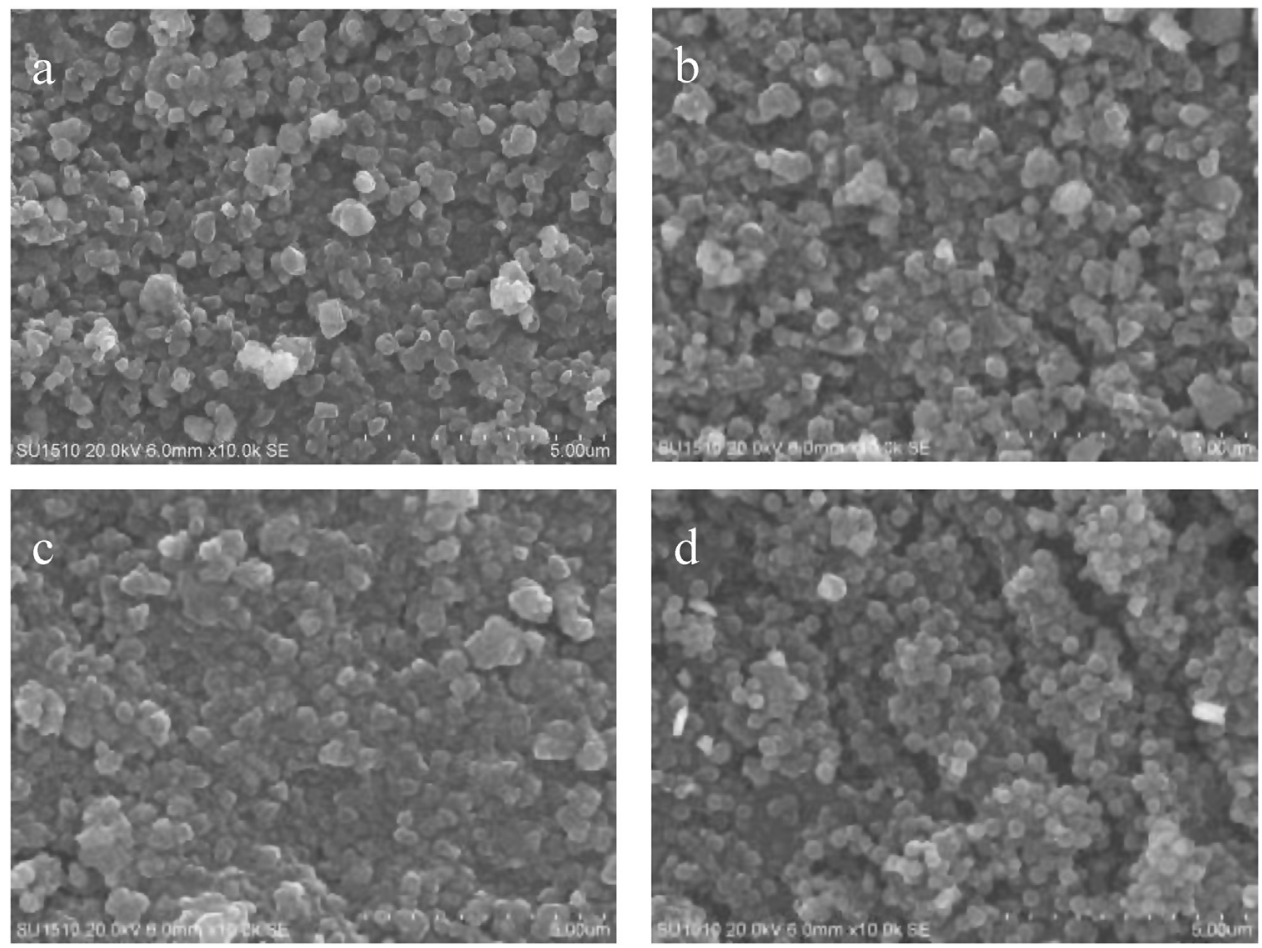

Fig. 5. SEM images of the (a) Pt/H-Beta-SDS-4, (b) Pt/H-Beta-SDS-8, (c) Pt/H-Beta-SDS-10, and (d) Pt/H-Beta-TEA-12 catalysts.

Table 2

Reactant order in the HCHO oxidation over the Pt/H-Beta-SDS and Pt/H-Beta-TEA samples.

\begin{tabular}{lll}
\hline Catalyst & HCHO order & Oxygen order \\
\hline Pt/H-Beta-SDS-4 & 0.711 & 1.302 \\
Pt/H-Beta-SDS-8 & 0.720 & 1.336 \\
Pt/H-Beta-SDS-10 & 0.729 & 1.361 \\
Pt/H-Beta-TEA-12 & 0.731 & 1.385 \\
\hline
\end{tabular}

order of HCHO and oxygen has been investigated according to the equation in the following:

$\ln \mathrm{R}=x \ln [\mathrm{A}]+$ constant

where $\mathrm{R}$ is the reaction rate, $[\mathrm{A}]$ is the reactant concentration, and $x$ is the reactant order. The $x$ could be obtained from the slope of a graph of $\ln R$ as a function of $\ln [\mathrm{A}]$, as calculated in Fig. 8 and presented in Table 2. Notably, compared with the other samples, the order of both HCHO and oxygen over the Pt/H-Beta-SDS-4 is significantly reduced. The reduction of the oxygen order should be assigned to improved Pt dispersion, while the decrease of $\mathrm{HCHO}$ order could be attributed to increased acidic density in the samples. The dependences of the reactant order on the Pt dispersion or $\mathrm{Si} / \mathrm{Al}$ ratio are given in Figs. S12 and S13 . Higher Pt dispersion should result in a larger oxygen adsorption capacity, improving the reaction rate. As a result, the oxygen order should be reduced. At the same time, higher acidic density should be favorable for the adsorption of HCHO molecules, enhancing the reaction rate. These results strongly support the design strategies for enhancing activity over zeolite-supported noble metal samples in the complete oxidation of $\mathrm{HCHO}$ at low temperatures, particularly room temperature.

Generally, the complete oxidation of HCHO mainly involves (i) oxidation of $\mathrm{HCHO}$ to formate species, (ii) decomposition of the formate species, and (iii) formation of $\mathrm{CO}_{2}$ and $\mathrm{H}_{2} \mathrm{O}$ by oxidation of the decomposed species [50,51]. The combination of step (ii) and step (iii) could be considered the oxidation of $\mathrm{HCOOH}$ to $\mathrm{CO}_{2}$ and $\mathrm{H}_{2} \mathrm{O}$. In the case of a titania-supported Pt sample with sodium modifications $\left(\mathrm{Na}-\mathrm{Pt} / \mathrm{TiO}_{2}\right.$, one of the most active for the complete oxidation of $\mathrm{HCHO}$ ), the decomposition of the formate species is regarded as the rate-determining step, where the additive such as sodium species play a critical role in the complete oxidation of $\mathrm{HCHO}$ at room temperature [43-45,48,50,53]. According to this idea, we have rationally prepared Pt/Beta-SDS- 4 samples with modified alkali cations $\left(\mathrm{Na}^{+}\right.$or $\left.\mathrm{K}^{+}\right)$, which have been denoted as $\mathrm{Pt} / \mathrm{Na}-\mathrm{Beta}-\mathrm{SDS}-4$ and Pt/K-Beta-SDS-4, respectively. Although the $\mathrm{Pt} / \mathrm{Na}-\mathrm{Beta}-\mathrm{SDS}-4$ and $\mathrm{Pt} / \mathrm{K}$-Beta-SDS-4 samples have very similar crystallinity, $\mathrm{Si} / \mathrm{Al}$ ratios, and $\mathrm{Pt}$ loading to those of the $\mathrm{Pt} / \mathrm{H}-\mathrm{Beta}-$ SDS-4 (Figs. 9 and S14-S16 and Table S4), they exhibit much lower activities than the Pt/H-Beta-SDS-4, as shown in Fig. S17. The temperature for complete oxidation of $\mathrm{HCHO}$ over Pt/Na-Beta- 

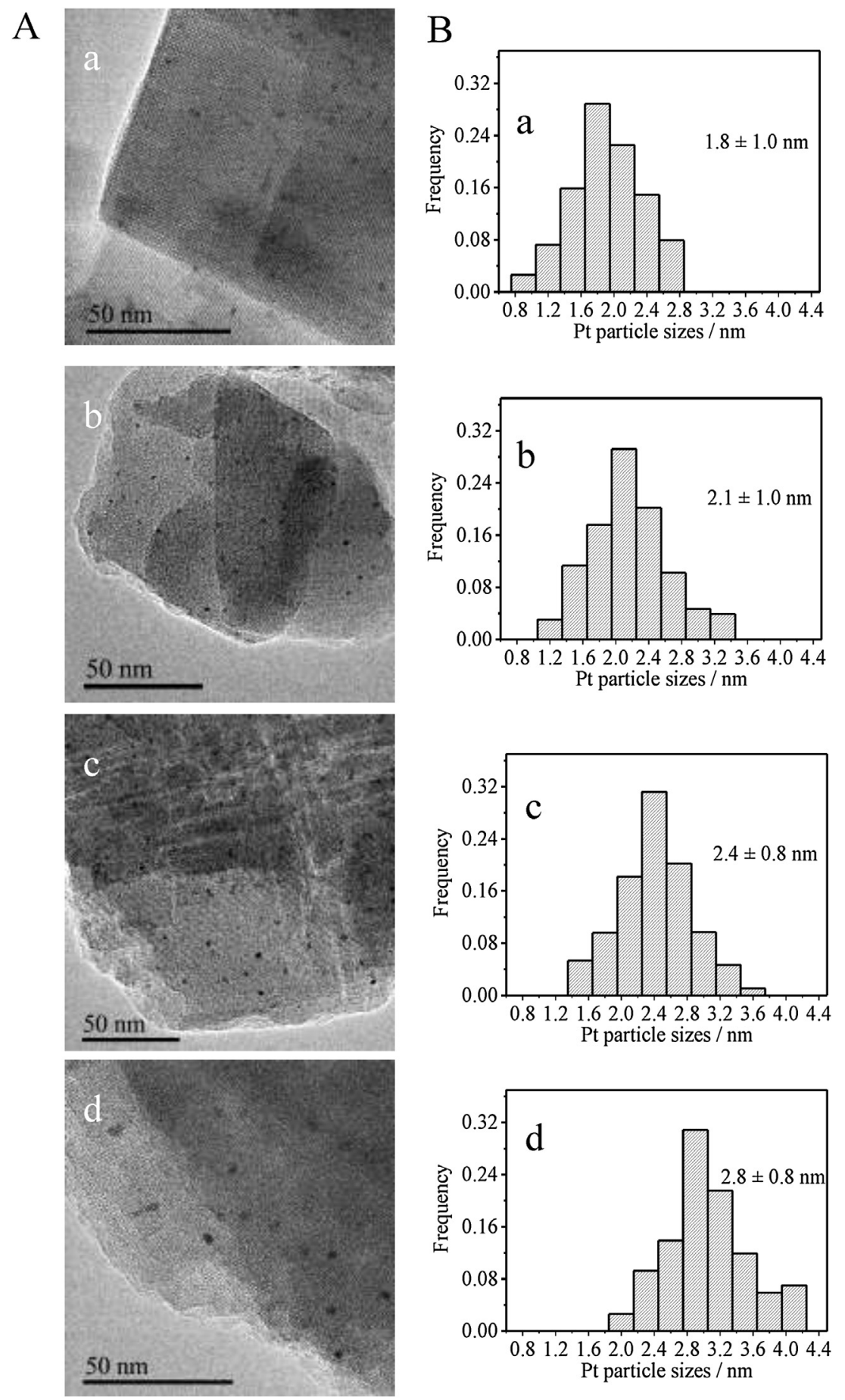

Fig. 6. (A) HRTEM images and (B) Pt particle size distribution of (a) Pt/H-Beta-SDS-4, (b) Pt/H-Beta-SDS-8, (c) Pt/H-Beta-SDS-10, and (d) Pt/H-Beta-TEA-12 catalysts.

SDS-4 and Pt/K-Beta-SDS- 4 exceeds $140{ }^{\circ} \mathrm{C}$. These results indicate that alkali cations are not suitable promoters of HCHO oxidation in zeolite-supported noble metal catalysts. These results also suggest that the mechanism on the $\mathrm{HCHO}$ oxidation over the $\mathrm{Pt} / \mathrm{H}-$ Beta-SDS-4 is quite different from that of conventional $\mathrm{Na}-\mathrm{Pt} / \mathrm{TiO}_{2}$ catalyst [50].

To understand a key step in the HCHO oxidation over the zeolitesupported Pt catalysts, we have systematically investigated the kinetic rates of oxidation of $\mathrm{HCHO}$ to $\mathrm{CO}_{2}\left(r_{0}\right)$, oxidation of $\mathrm{HCHO}$ to $\mathrm{HCOOH}\left(r_{1}\right)$, and oxidation of $\mathrm{HCOOH}$ into $\mathrm{CO}_{2}\left(r_{2}\right)$ over the all catalysts, as given in Figs. 10 and S18-S19. Notably, the $r_{2}$ values of all samples are larger than their $r_{0}$ and $r_{1}$ values, indicating that the key step for the complete oxidation of $\mathrm{HCHO}$ over the zeolite Beta supported noble samples should be the oxidation of $\mathrm{HCHO}$ to $\mathrm{HCOOH}$, rather than the oxidation of $\mathrm{HCOOH}$ to $\mathrm{CO}_{2}$. Particularly, in these $\mathrm{Pt} / \mathrm{H}$-Beta catalysts, the $r_{1}$ values significantly increase with the decrease of the Si/Al ratios, which is strongly related to the acidic contribution for the conversion of $\mathrm{HCHO}$ to $\mathrm{HCOOH}$. This feature is quite different from the results obtained from the Na$\mathrm{Pt} / \mathrm{TiO}_{2}$ sample [50]. In the $\mathrm{Na}-\mathrm{Pt} / \mathrm{TiO}_{2}$ catalyzed $\mathrm{HCHO}$ oxidation, the rate of $\mathrm{HCOOH}$ to $\mathrm{CO}_{2}$ is effectively enhanced. In contrast, in the Pt/H-Beta-SDS- 4 catalyzed $\mathrm{HCHO}$ oxidation, the rate of $\mathrm{HCHO}$ 


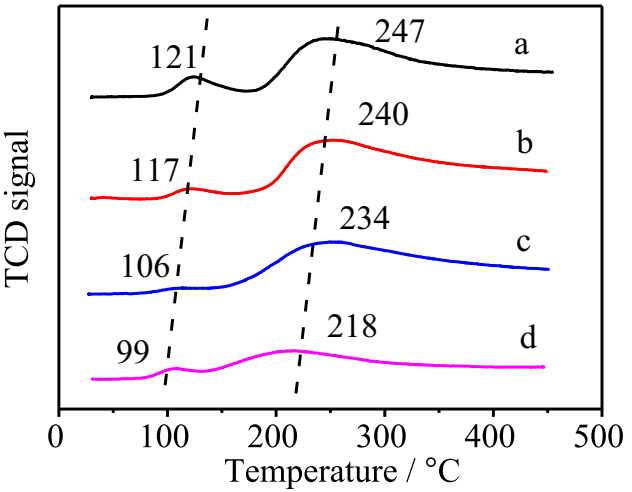

Fig. 7. HCHO-TPD curves of (a) Pt/H-Beta-SDS-4, (b) Pt/H-Beta-SDS-8, (c) Pt/H-BetaSDS-10, and (d) Pt/H-Beta-TEA-12 catalysts.

to $\mathrm{HCOOH}$ is significantly improved. In addition, the replacement of alkali cations with protons in these zeolite-supported Pt catalysts remarkably enhances the activity, confirming the important contribution of acidic sites for oxidation of $\mathrm{HCHO}$ to $\mathrm{HCOOH}$. These data are well consistent with those of the oxidation of glycerol over the zeolite-based Pt catalysts, where the high acidic density is favorable for the activation of oxygenates [71].

\section{Conclusion}

In summary, Al-rich Beta zeolite supported Pt sample (Pt/HBeta-SDS-4) exhibits high activity, excellent selectivity for $\mathrm{CO}_{2}$, and extraordinary durability in the complete oxidation of $\mathrm{HCHO}$ at room temperature, which is very important for the removal of indoor air pollutants. The superior properties of this sample result from the comprehensive contribution of highly dispersed Pt nanoparticles and a high density of acidic sites, which are related to the choice of Al-rich Beta zeolite support, where the abundant aluminum species in the zeolite framework not only improve the high acidic density but also enhance the interaction of positively charged noble met-
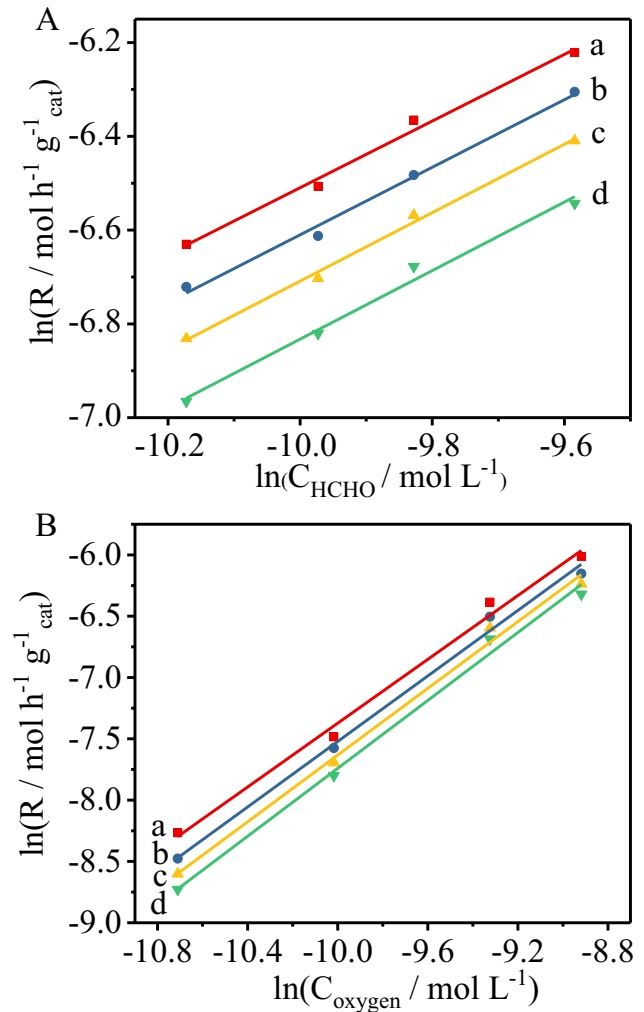

Fig. 8. Estimation of (A) HCHO and (B) oxygen orders from the dependence of kinetic rate on the reactant concentration in the $\mathrm{HCHO}$ oxidation over the (a) $\mathrm{Pt} / \mathrm{H}$-Beta-SDS4, (b) Pt/H-Beta-SDS-8, (c) Pt/H-Beta-SDS-10, and (d) Pt/H-Beta-TEA-12 catalysts.

als and the negatively charged zeolite framework. The strategy of designing zeolite-supported noble metal catalysts might offer an alternative way to develop highly efficient heterogeneous catalysts for the removal of air pollutants.
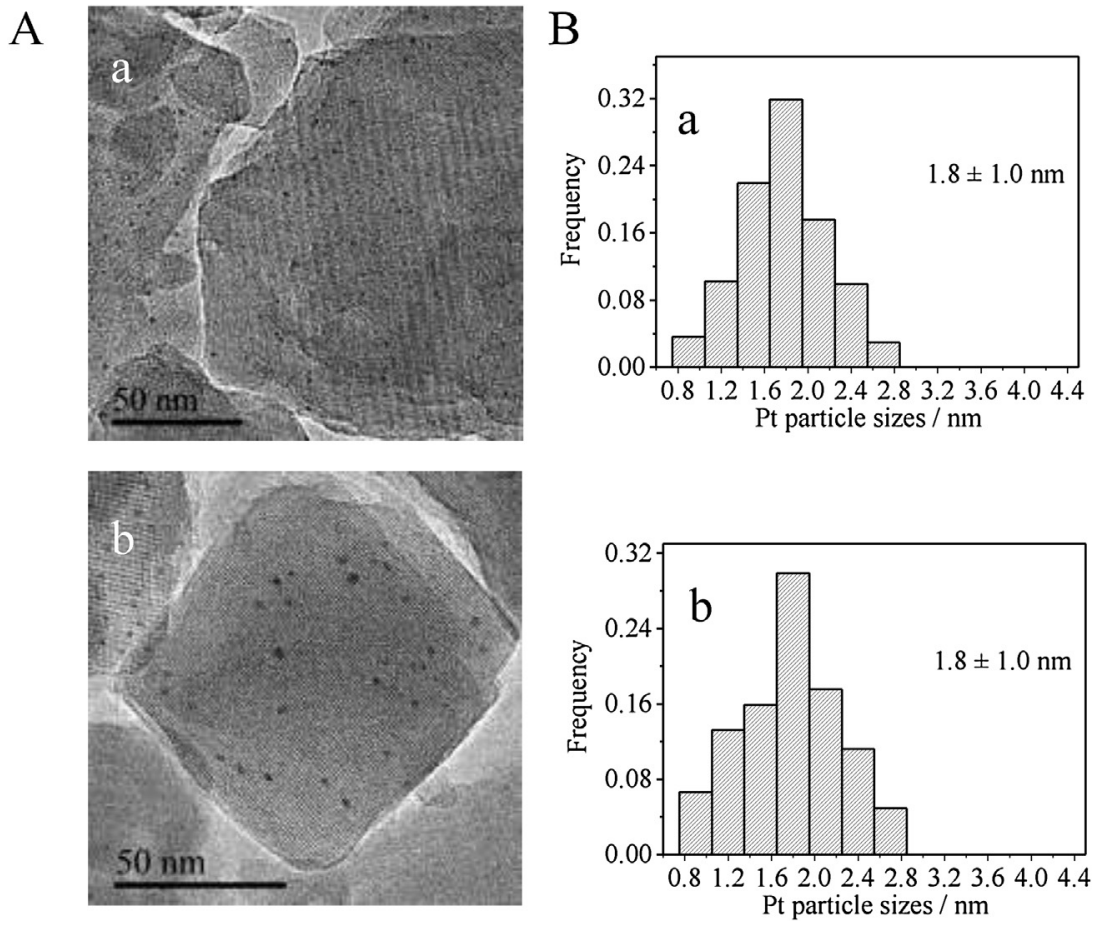

Fig. 9. (A) HR-TEM images and (B) Pt particle size distribution of (c) Pt/Na-Beta-SDS-4 and (d) Pt/K-Beta-SDS-4 samples. 

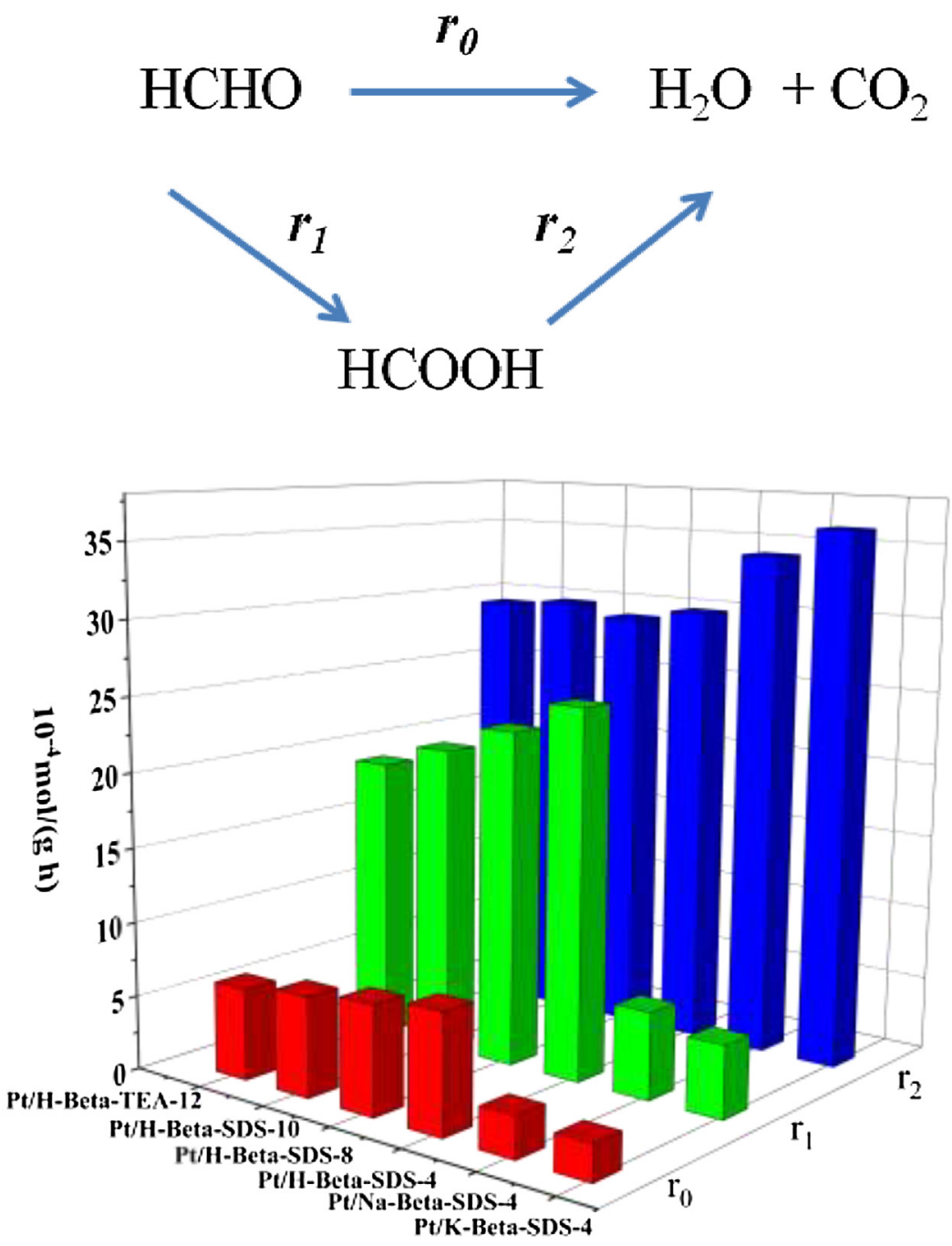

Fig. 10. Kinetic rates of oxidation of $\mathrm{HCHO}$ to $\mathrm{CO}_{2}$ and $\mathrm{H}_{2} \mathrm{O}$, oxidation of $\mathrm{HCHO}$ to $\mathrm{HCOOH}$, and oxidation of $\mathrm{HCOOH}$ to $\mathrm{CO}_{2}$ and $\mathrm{H}_{2} \mathrm{O}$ over various Pt/Beta catalysts.

\section{Acknowledgments}

This work is supported by the National Natural Science Foundation of China (21673205, 21333009 and 21422306) and the Zhejiang Provincial Natural Science Foundation of China (Grant Nos. LR15B030001 and LY16B030004).

\section{Appendix A. Supplementary data}

Supplementary data associated with this article can be found, in the online version, at http://dx.doi.org/10.1016/j.apcatb.2017. 07.015.

\section{References}

[1] A.P. Jones, Atmos. Environ. 33 (1999) 4535-4564.

[2] C. Yu, D. Crump, Build. Environ. 33 (1998) 357-374.

[3] T. Salthammer, S. Mentese, R. Marutzky, Chem. Rev. 110 (2010) 2536-2572.

[4] B.Y. Bai, Q. Qiao, J.H. Li, J.M. Hao, Chin. J. Catal. 37 (2016) 102-122.

[5] B.Y. Bai, Q. Qiao, H. Arandiyan, J.H. Li, J.M. Hao, Environ. Sci. Technol. 50 (2016) 2635-2640.

[6] D.W. Kwon, P.W. Seo, G.J. Kim, S.C. Hong, Appl. Catal. B Environ. 163 (2015) 436-443.

[7] J. Wang, P. Zhang, J. Li, C. Jiang, R. Yunus, J. Kim, Environ. Sci. Technol. 49 (2015) 12372-12379.

[8] Q. Xu, W. Lei, X. Li, X. Qi, J. Yu, G. Liu, J. Wang, P. Zhang, Environ. Sci. Technol. 48 (2014) 9702-9708.

[9] X.J. Tang, Y. Bai, A. Duong, M.T. Smith, L.Y. Li, L.P. Zhang, Environ. Int. 35 (2009) 1210-1224.
[10] J.J. Collins, R. Ness, R.W. Tyl, N. Krivanek, N.A. Esmen, T.A. Hall, Regul Toxicol Pharm. 34 (2001) 17-34.

[11] J. Wang, J. Li, C. Jiang, P. Zhou, P. Zhang, J. Yu, Appl. Catal. B Environ. 204 (2017) 147-155.

[12] Z. Xu, J. Yu, M. Jaroniec, Appl. Catal. B Environ. 163 (2015) 306-312.

[13] Z. Yan, Z. Xu, J. Yu, M. Jaroniec, Appl. Catal. B Environ. 199 (2016) 458-465.

[14] T. Yang, Y. Huo, Y. Liu, Z. Rui, H. Ji, Appl. Catal. B Environ. 200 (2017) 543-551.

[15] H.Q. Rong, Z.Y. Liu, Q.L. Wu, D. Pan, J.T. Zheng, Cellulose 17 (2010) 205-214.

[16] J.J. Pei, J.S.S. Zhang, Chem. Eng. J. 167 (2011) 59-66.

[17] Y.S. Tao, H. Kanoh, L. Abrams, K. Kaneko, Chem. Rev. 106 (2006) 896-910.

[18] J.P. Bellat, I. Bezverkhyy, G. Weber, S. Royer, R. Averlant, J.M. Giraudon, J.F. Lamonier, J. Hazard. Mater. 300 (2015) 711-717.

[19] P.A. Bourgeois, E. Puzenat, L. Peruchon, F. Simonet, D. Chevalier, E. Deflin, C. Brochier, C. Guillard, Appl. Catal. B Environ. 128 (2012) 171-178.

[20] Y.W. Lu, D.H. Wang, C.F. Ma, H.C. Yang, Build. Environ. 45 (2010) 615-621.

[21] F. Shiraishi, D. Ohkubo, K. Toyoda, S. Yamaguchi, Chem. Eng. J. 114 (2005) $153-159$.

[22] S.B. Wang, H.M. Ang, M.O. Tade, Environ. Int. 33 (2007) 694-705.

[23] T. Noguchi, A. Fujishima, Environ. Sci. Technol. 32 (1998) 3831-3833.

[24] G. Qin, Y. Zhang, X. Ke, X. Tong, Z. Sun, M. Liang, S. Xue, Appl. Catal. B Environ. 129 (2013) 599-605.

[25] Y. Huang, B. Long, M. Tang, Z. Rui, M.-S. Balogun, Y. Tong, H. Ji, Appl. Catal. B Environ. 181 (2016) 779-787.

[26] B.Y. Dong, S.R. Lan, J. Phys. Conf. Ser. (2013) 418.

[27] X. Zhu, X. Gao, R. Qin, Y. Zeng, R. Qu, C. Zheng, X. Tu, Appl. Catal. B Environ. 170-171 (2015) 293-300.

[28] D.Z. Zhao, X.S. Li, C. Shi, H.Y. Fan, A.M. Zhu, Chem. Eng. Sci. 66 (2011) 3922-3929.

[29] M.B. Chang, C.C. Lee, Environ. Sci. Technol. 29 (1995) 181-186.

[30] B.Y. Bai, H. Arandiyan, J.H. Li, Appl. Catal. B Environ. 142 (2013) 677-683.

[31] C. Shi, Y. Wang, A.M. Zhu, B.B. Chen, C. Au, Catal. Commun. 28 (2012) 18-22.

[32] C. Shi, B.B. Chen, X.S. Li, M. Crocker, Y. Wang, A.M. Zhu, Chem. Eng. J. 200 (2012) 729-737. 
[33] D.Z. Zhao, T.Y. Ding, X.S. Li, J.L. Liu, C.A. Shi, A.M. Zhu, Chin. J. Catal. 33 (2012) 396-401.

[34] D.Z. Zhao, C. Shi, X.S. Li, A.M. Zhu, B.W.L. Jang, J. Hazard. Mater. 239 (2012) 362-369.

[35] B.B. Chen, C. Shi, M. Crocker, Y. Wang, A.M. Zhu, Appl. Catal. B Environ. $132-133$ (2013) 245-255.

[36] B.B. Chen, X.B. Zhu, M. Crocker, Y. Wang, C. Shi, Appl. Catal. B Environ. 154-155 (2014) 73-81.

[37] P. Liu, H. He, G. Wei, X. Liang, F. Qi, F. Tan, W. Tan, J. Zhu, R. Zhu, Appl. Catal. B Environ. 182 (2016) 476-484.

[38] T. Chen, H.Y. Dou, X.L. Li, X.F. Tang, J.H. Li, J.M. Hao, Microporous Mesoporous Mater. 122 (2009) 270-274.

[39] S. Imamura, D. Uchihori, K. Utani, T. Ito, Catal. Lett. 24 (1994) 377-384.

[40] X.F. Tang, J.H. Li, J.M. Hao, Catal. Commun. 11 (2010) 871-875.

[41] X.F. Tang, Y.G. Li, X.M. Huang, Y.D. Xu, H.Q. Zhu, J.G. Wang, W.J. Shen, Appl. Catal. B Environ. 62 (2006) 265-273.

[42] Y.R. Wen, X. Tang, J.H. Li, J.M. Hao, L.S. Wei, X.F. Tang, Catal. Commun. 10 (2009) 1157-1160.

[43] C.B. Zhang, H. He, K. Tanaka, Catal. Commun. 6 (2005) 211-214.

[44] C.B. Zhang, H. He, K. Tanaka, Appl. Catal. B Environ. 65 (2006) 37-43.

[45] C.B. Zhang, H. He, Catal. Today 126 (2007) 345-350.

[46] X. Tang, J. Chen, X. Huang, Y. Xu, W. Shen, Appl. Catal. B Environ. 81 (2008) $115-121$.

[47] J. Xu, T. White, P. Li, C.H. He, Y.F. Han, J. Am. Chem. Soc. 132 (2010) $13172-13173$.

[48] H.B. Huang, D.Y.C. Leung, ACS Catal. 1 (2011) 348-354.

[49] Z. Huang, X. Gu, Q. Cao, P. Hu, J. Hao, J. Li, X. Tang, Angew. Chem. 51 (2012) 4198-4203.

[50] C. Zhang, F. Liu, Y. Zhai, H. Ariga, N. Yi, Y. Liu, K. Asakura, M. Flytzani-Stephanopoulos, H. He, Angew. Chem. 51 (2012) 9628-9632.

[51] L.H. Nie, J.G. Yu, X.Y. Li, B. Cheng, G. Liu, M. Jaroniec, Environ. Sci. Technol. 47 (2013) 2777-2783.

[52] J.Q. Torres, S. Royer, J.P. Bellat, J.M. Giraudon, J.F. Lamonier, ChemSusChem 6 (2013) 578-592.

[53] C.B. Zhang, Y.B. Li, Y.F. Wang, H. He, Environ. Sci. Technol. 48 (2014) $5816-5822$.

[54] J.H. Zhang, Y.B. Li, L. Wang, C.B. Zhang, H. He, Catal. Sci. Technol. 5 (2015) 2305-2313.

[55] X.L. Liang, P. Liu, H.P. He, G.L. Wei, T.H. Chen, W. Tan, F.D. Tan, J.X. Zhu, R.L. Zhu, J. Hazard. Mater. 306 (2016) 305-312.
[56] J.X. Peng, S.D. Wang, Appl. Catal. B Environ. 73 (2007) 282-291.

[57] L.H. Nie, J.G. Yu, J.W. Fu, ChemCatChem 6 (2014) 1983-1989.

[58] L.H. Nie, P. Zhou, J.G. Yu, M. Jaroniec, J. Mol. Catal. A Chem. 390 (2014) 7-13.

[59] L.F. Qi, B. Cheng, J.G. Yu, W.K. Ho, J. Hazard. Mater. 301 (2016) 522-530.

[60] M.C. Alvarez-Galvan, V.A.D.P. O'Shea, J.L.G. Fierro, P.L. Arias, Catal. Commun. 4 (2003) 223-228.

[61] M.C. Alvarez-Galvan, B. Pawelec, V.A.D. O’Shea, J.L.G. Fierro, P.L. Arias, Appl. Catal. B Environ. 51 (2004) 83-91.

[62] V.A.D.P. O’Shea, M.C. Alvarez-Galvan, J.L.G. Fierro, P.L. Arias, Appl. Catal. B Environ. 57 (2005) 191-199.

[63] C.F. Mao, M.A. Vannice, J. Catal. 154 (1995) 230-244.

[64] Z.P. Qu, S.J. Shen, D. Chen, Y. Wang, J. Mol. Catal. A Chem. 356 (2012) 171-177.

[65] N.H. An, W.L. Zhang, X.L. Yuan, B. Pan, G. Liu, M.J. Jia, W.F. Yan, W.X. Zhang, Chem. Eng. J. 215 (2013) 1-6.

[66] A. Corma, Chem. Rev. 95 (1995) 559-614

[67] A. Corma, Chem. Rev. 97 (1997) 2373-2419.

[68] M.E. Davis, Nature 417 (2002) 813-821.

[69] S.J. Park, I. Bae, I.S. Nam, B.K. Cho, S.M. Jung, J.H. Lee, Chem. Eng. J. 195 (2012) $392-402$.

[70] L. Zhang, Y.X. Peng, J. Zhang, L. Chen, X.J. Meng, F.S. Xiao, Chin. J. Catal. 37 (2016) 800-809.

[71] A. Villa, G.M. Veith, L. Prati, Angew. Chem. Int. Ed. 49 (2010) 4499-4502.

[72] A. Corma, A. Martinez, V. MartinezSoria, J. Catal. 169 (1997) 480-489.

[73] S.J. Tauster, S.C. Fung, R.T.K. Baker, J.A. Horsley, Science 211 (1981) 1121-1125.

[74] B. Xie, H.Y. Zhang, C.G. Yang, S.Y. Liu, L.M. Ren, L. Zhang, X.J. Meng, B. Yilmaz, U. Muller, F.-S. Xiao, Chem. Commun. 47 (2011) 3945-3947.

[75] B. Xie, J.W. Song, L.M. Ren, Y.Y. Ji, J.X. Li, F.-S. Xiao, Chem. Mater. 20 (2008) $4533-4535$.

[76] S. Suganuma, H.Y. Zhang, C.G. Yang, F.S. Xiao, N. Katada, J. Porous Mater. 23 (2016) 415-421

[77] H.Y. Zhang, B. Xie, X.J. Meng, U. Muller, B. Yilmaz, M. Feyen, S. Maurer, H. Gies, T. Tatsumi, X.H. Bao, W.P. Zhang, D. De Vos, F.-S. Xiao, Microporous Mesoporous Mater. 180 (2013) 123-129.

[78] C. Chen, Q. Wu, F. Chen, L. Zhang, S. Pan, C. Bian, X. Zheng, X. Meng, F.-S. Xiao, J. Mater. Chem. A 3 (2015) 5556-5562.

[79] J. Zhang, Y. Li, Y. Zhang, M. Chen, L. Wang, C. Zhang, H. He, Sci. Rep. 5 (2015) 12950.

[80] H.Y. Chen, Z.B. Rui, X.Y. Wang, H.B. Ji, Catal. Today 258 (2015) 56-63.

[81] D. Ghita, P. Rosca, D.S. Ezeanu, Rev. Chim-Bucharest 63 (2012) 1056-1061.

[82] S. Damyanova, J.M.C. Bueno, Appl. Catal. A-Gen. 253 (2003) 135-150. 